\title{
Understanding the dramatic therapeutic play session: a contribution to pediatric nursing
}

\author{
Compreendendo a sessão de brinquedo terapêutico dramático: contribuição para a enfermagem pediátrica \\ Entender la sesión de juego terapéutico dramático: una contribución a la enfermería pediátrica
}

\section{Entender la sesión de juego terapéutico Vera Lucia Alves dos Santos'
ORCID: 0000-0002-8011-3210
Fabiane de Amorim Almeida"
ORCID: 0000-0002-8062-3579
Carina Ceribelli"'
ORCID: 0000-0002-6091-5056
Circéa Amália Ribeiro'v
ORCID: 0000-0001-8215-0296}

'Grupo de Estudos do Brinquedo. São Paulo, São Paulo, Brazil. "Faculdade de Enfermagem do Hospital Israelita Albert Einstein. São Paulo, São Paulo, Brazil. I'Faculdades Metropolitanas Unidas. São Paulo, São Paulo, Brazil. "Universidade Federal de São Paulo. São Paulo, São Paulo, Brazil.

How to cite this article: Santos VLA, Almeida FA, Ceribelli C, Ribeiro CA. Understanding the dramatic therapeutic play session: a contribution to pediatric nursing. Rev Bras Enferm. 2020;73(4):e20180812. doi: http://dx.doi.org/10.1590/0034-7167-2018-0812

Corresponding author:

Vera Lucia Alves dos Santos

E-mail: saudecriancaadolescente@gmail.com

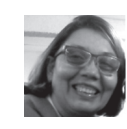

EDITOR IN CHIEF: Antonio José de Almeida Filho ASSOCIATE EDITOR: Priscilla Valladares Broca

Submission: $04-25-2019$

Approval: 06-17-2019

\begin{abstract}
Objectives: to understand how the dramatic therapeutic play session occurs within the care of hospitalized children. Methods: qualitative multiple case study, using theoretical references, such as symbolic interactionism and Vygotsky's theory of symbolic play. Twenty play sessions performed with six children from 3 to 10 years old were analyzed, each corresponding to one case. Results: these sessions demonstrated that a dramatic therapeutic play session is a process of four interdependent and complementary steps: bonding, exploring, dramatizing, and play cessation. They also revealed the imaginary situations externalized by the child, the importance of the exploration step for which they manage the imaginary situation and catharsis, and how her higher psychological faculties are articulated during this process. Final Considerations: the results contribute to the understanding of the conduct and analysis of the dramatic therapeutic play session, reinforcing the importance of its use in pediatric nursing care practice.

Descriptors: Play and Playthings; Child, Hospitalized; Pediatric Nursing; Nursing Care; Child Care.
\end{abstract}

\section{RESUMO}

Objetivos: compreender como transcorre uma sessão de Brinquedo Terapêutico Dramático na assistência à criança hospitalizada. Métodos: estudo de casos múltiplos, qualitativo, sendo referenciais teóricos o Interacionismo Simbólico e a Teoria de Vygotsky sobre a brincadeira simbólica. Analisaram-se vinte sessões de brinquedo, realizadas com seis crianças de 3 a 10 anos de idade, cada uma correspondendo a um caso. Resultados: mostraram que a sessão de Brinquedo Terapêutico Dramático é um processo de quatro etapas interdependentes e complementares: Estabelecendo vínculo, Explorando, Dramatizando e Parando de brincar. Revelaram, também, as situações imaginárias exteriorizadas pela criança, a importância da etapa da exploração para que ela geste a situação imaginária e ocorra a catarse, e como se articulam suas faculdades psicológicas superiores durante esse processo. Considerações Finais: os resultados trazem contribuição à compreensão da condução e análise da sessão de Brinquedo Terapêutico, reforçando a importância de sua utilização na prática assistencial em enfermagem pediátrica.

Descritores: Jogos e Brinquedos; Criança Hospitalizada; Enfermagem Pediátrica; Cuidados de Enfermagem; Cuidado da Criança.

\section{RESUMEN}

Objetivos: comprender cómo se lleva a cabo la sesión de juego terapéutico dramático en el cuidado de niños hospitalizados. Métodos: estudio de caso cualitativo múltiple, con referencias teóricas como el interaccionismo simbólico y la teoría del juego simbólico de Vygotsky. Se analizaron veinte sesiones de juguetes, realizadas con seis niños de 3 a 10 años, cada uno correspondiente a un caso. Resultados: se demostró que la sesión de juego terapéutico dramático es un proceso de cuatro pasos interdependientes y complementarios: vinculación, exploración, dramatización y detenimiento del juego. También revelaron las situaciones imaginarias externalizadas por la niña, la importancia de la etapa de exploración para la que maneja la situación imaginaria y la catarsis, y cómo se articulan sus facultades psicológicas superior durante este proceso. Consideraciones Finales: los resultados contribuyen a la comprensión de la conducta y el análisis de la sesión de juguete terapéutico, lo que refuerza la importancia de su uso en la práctica de cuidados de enfermería pediátrica.

Descriptores: Juego e Implementos de Juego; Niño Hospitalizado; Enfermería Pediátrica; Atención de Enfermería; Cuidado del Niño. 


\section{INTRODUCTION}

Therapeutic play (TP), as proposed by Steele $\mathrm{e}^{(1)}$, is an important nursing intervention strategy in the care of children and adolescents, and is widely reported in the literature ${ }^{(2-9)}$. It is a form of structured play, with objectives of enabling children to release tension and of preparing them for procedures by means of dramatization. This facilitates children in their understanding of uncomfortable, threatening, painful, or atypical experiences for their age, and helps nurses to understand their needs ${ }^{(10-12)}$.

One of the types of TP is dramatic (DTP), which enables the child to express feelings, fantasies, desires, and lived experiences, as well as to externalize relationships and social roles internalized by him/her using dramatizing situations in play ${ }^{(11-14)}$.

The Federal Council of Nurses, in Resolution No. 0546, 2017, emphasized the importance of TP, stating that: "It is the responsibility of nurses working in the pediatric area, as a member of the multi-professional health team, to use Play/Therapeutic Play technique, in providing care for the hospitalized child and family", and the nurse is responsible for prescription and supervision of these activities (COFEN, 2017)(15).

Even with the legal incentive, its application in practice is still modest ${ }^{(7,16)}$, due to factors such as insufficient material and human resources, overload of activities, lack of time and support from the institution, whose philosophy does not always privilege playing in health care, as well as lack of knowledge and insecurity in applying it ${ }^{(7,12,14,17-21)}$.

The difficulties stated by nurses for the routine use of TP include a lack of ability to perform this type of play and interpret the child's manifestations when playing ${ }^{(7,18)}$. This fact has also been observed in our professional practice, and in the reports of nurses of pediatric hospital units, few of whom are confident to use TP in their daily lives, although they received information on it in their academic education.

Reflecting on the dynamics of a DTP session, some questions emerged: Is it possible to recognize different steps in the evolution of similar sessions? Do they change between different sessions with the same child?

The search in databases and virtual libraries as Scielo, Medline, Wiley Online Library, and Cochrane Library, using the descriptors "Play and toys", "Therapeutic play", "Hospitalized child", "Pediatric nursing", "Nursing care" and "Child care", showed that despite there being several articles on TP used by nurses, no studies were found focusing on understanding how the TP session proceeds, or the possible steps.

Reflection on the lack of consistent knowledge regarding the use of TP by nurses in practice, and the inability to find studies that focus on the TP session itself, contribute to the relevance of this study in providing support that enables understanding of this type of play.

It is expected that the results of this study will contribute to the development of more consistent knowledge about TP, so that this intervention can be included with greater safety and mastery in nursing care activities.

\section{OBJECTIVES}

To understand how the DTP session happens within the care of hospitalized children, and to recognize the imaginary situations dramatized during the DTP session, based on the child's verbal and nonverbal manifestations.

\section{METHODS}

\section{Theoretical framework}

The theoretical frameworks that guided data analysis were symbolic interactionism ( $\mathrm{SI}$ ) and Vygotsky's theory on the child's symbolic play. The SI is a perspective of analysis of human experience focusing on the interaction of the individual with his social reality, which leads him to a process of meaning for each experience, and guides his action ${ }^{(22)}$.

According to Vygotsky, an imaginary situation is the defining characteristic of toys, composing the "emotional atmosphere" of play. Playing mainly involves the ability to imagine, one of the higher psychological functions and unique intellectual abilities of the human being, as a manner for the child to understand the world around him, to meet his needs, and to seek solutions to problems or difficulties that may be afflicting him ${ }^{(23)}$.

The context of the imaginary situation is determined by the child's motivation to play and the objects chosen by him assume the meaning he attributes to them ${ }^{(23)}$. An example could be a hospitalized child who, when playing, uses an empty syringe, initially, as a small fan, and at another time uses it to give a doll an injection.

The child's statement also plays an important role in symbolic play, which, according to Vygotsky, can be understood as a very complex system of speech using gestures, which communicate and indicate the meanings of the objects used to play(23).

\section{Type of study}

This was a multiple case study with a qualitative approach. The case study is defined as an empirical investigation of the "how" and "why" of a contemporary phenomenon, in its real context, and without control over events. It refers to a holistic analysis technique, which considers the social unit studied as a whole: a community, institution, family, or individual, seeking to understand the case in its own terms ${ }^{(24)}$. This approach addresses the questions and conditions of this study.

Multiple case studies are used when the evidence needs to be more convincing, and are present in more than one case. Each case is replicated, based on the same structure, and its results are individually analyzed according to the same criteria, resulting in a unique set of conclusions ${ }^{(24)}$.

\section{Methodological procedures}

\section{Scenario}

The scenario of this study was the pediatric unit of a state teaching hospital in the Baixada Santista metropolitan region, which serves children from clinical and surgical specialties.

\section{Data source}

Six children were included, aged three to ten years old, of both sexes, hospitalized for different diseases, who were available to 
play and agreed to participate in the study, giving verbal consent. The legal guardians signed the Terms of Free and Informed Consent form, agreeing to participation in the research. They were, initially selected by analysis of a general list of children hospitalized in the unit, by the nurses'indication, or by the child's own desire to participate.

\section{Data collection procedure}

The document analysis of the child's clinical records and the observation of the TP sessions were video recorded and transcribed in their entirety, for later analysis.

The TP sessions, conducted by one of the researchers, followed the steps recommended in the literature: invite the child to play; consult with him/her about the mother's remaining during the play, and the desired place to play; present him/her the material available for play without immediately identifying them; guide him/her regarding the time for play, and the return of the material at the end of the session; let him/her play freely, without conducting a game; reflect only the child's verbal expressions so that he/she feels accepted, respected and encouraged to continue playing; repeat to the child the question made by him/her; notifies him/her about the end of the session, so that he/she can be prepared for it ${ }^{(11)}$.

The material offered for play by the child was composed of dolls representative of the family (adult couples, seniors, children, one baby, and domestic animals) and the hospital staff (men and women dressed in white); articles for domestic use (cutlery, cups, saucers, pans, jars, and trays), hospital use (syringes, needles, intravenous hydration equipment, stethoscope, among others); mobile phone, wooden cart, geometric blocks, drawing and coloring material, and colorful wooden animals and dolls representing a farm. This assorted material, recommended in the literature, is important for the child be able to dramatize domestic and hospital situations, to express feelings of anger and hostility, regressive feelings, and to express themselves freely ${ }^{(11)}$.

\section{Data analysis}

Analysis was performed concurrently with data collection. Therefore, the recordings of the sessions were reviewed several times, transcribed entirely, and analyzed based on the elements that define playing, according to the adopted theoretical references and the study objectives.

The following aspects were considered: evidence of the presence of imaginary situations, considering the moment of the session in which it occurred, what preceded and succeeded it, as well as its consequences and meanings attributed by the child to the toys in the imaginary situation; child's motivation with the toy; the child's reactions/manifestations, verbal or nonverbal, and the circumstance that triggered them; the statement of the child as a mediator in solving conflicts or overcoming difficulties presented by them; the sequence of events during the session; possible relationship with different aspects of the child's life, such as family, friends, illness and hospitalization; the factors that interfered with or influenced the session, such as presence of other children, presence or absence of mother, pain, malaise, presence or absence of any member of the hospital team; and a comparison between information on the child and previous history of hospitalization with the findings in the TP session.

This process was used in each session, individually, identifying the important events and steps in each. Then, the findings of each session were synthesized and organized in sequence, so that the steps of each of them could be visualized, in order to understand if they were repeated and what characterized them. This also enabled the visualization of how the sessions evolved in chronological succession, i.e., the differences between the first and the second session, the second and the third, etc.

\section{Ethical aspects}

This project was analyzed and reviewed, at a scientific meeting of the Play Study Group - GEBrinq, to which this study is associated, and approved by the Research Ethics Committee of the Federal University of São Paulo, under nº 0837 / 09, before the research began.

\section{RESULTS}

\section{Outlining the profile of children and DTP sessions}

Twenty DTP sessions were conducted with the six children, and which enabled a sufficient and consistent set of data to understand and describe the phenomenon studied; the set of sessions performed by the same child would constitute a case.

The children, hospitalized for different clinical and surgical diagnoses, were between three and ten years old, five boys and one girl. The number of DTP sessions ranged from two to five per child, lasting from 20 to 66 minutes per session. The variation in the number of sessions was due to the need for TP presented by each one. To ensure confidentiality of identity, each child chose the name under which they were assigned (Chart 1).

Chart 1 - Characteristics of children and therapeutic play sessions

\begin{tabular}{|c|c|c|c|c|c|c|c|c|}
\hline \multirow[t]{2}{*}{ Case } & \multirow{2}{*}{$\begin{array}{c}\text { Age } \\
\text { (in years) }\end{array}$} & \multirow{2}{*}{ Medical diagnosis } & \multirow{2}{*}{$\begin{array}{l}\text { Number of } \\
\text { sessions }\end{array}$} & \multicolumn{5}{|c|}{$\begin{array}{l}\text { Time of the sessions } \\
\text { (in minutes) }\end{array}$} \\
\hline & & & & $1^{\text {st }}$ & $2^{\text {nd }}$ & $3^{\text {rd }}$ & $4^{\text {th }}$ & $5^{\text {th }}$ \\
\hline Flavio & 9 & $\begin{array}{l}\text { Chronic kidney } \\
\text { failure and peritonitis }\end{array}$ & 4 & 40 & 44 & 45 & 13 & - \\
\hline Victoria & 10 & Appendicitis & 2 & 36 & 20 & - & - & - \\
\hline Sponge Bob & 10 & Hypospadia & 4 & 35 & 20 & 38 & 50 & - \\
\hline Spider-Man & 8 & Chronic diarrhea & 5 & 54 & 62 & 32 & 45 & 30 \\
\hline Batman & 5 & $\begin{array}{l}\text { Pneumonia and } \\
\text { Pleural effusion }\end{array}$ & 3 & 66 & 27 & 52 & - & - \\
\hline Ben 10 & 3 & $\begin{array}{c}\text { Decompensated } \\
\text { nephrotic syndrome }\end{array}$ & 2 & 24 & 22 & - & - & - \\
\hline
\end{tabular}




\section{Understanding the dynamics and structure of the DTP sessions}

The cases revealed that the DTP session is a process developed in four interdependent and complementary steps: "bonding"; "exploring"; "dramatizing", and "play cessation". Each step is characterized by one or more predominant and evident activities during the session, demonstrating a sequence, with periods of intersection and interdependence, highlighting the first step, "bonding", which supports all the others, as presented in Figure 1.

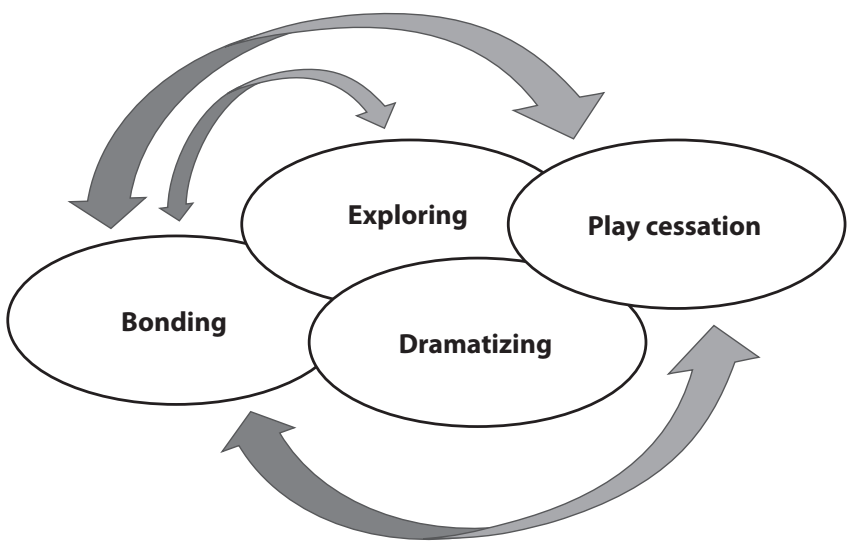

Figure 1 - Relationship between the steps that comprise the dramatic therapeutic play session

\section{Establishing bond}

In the course of the research, it was shown that the process of bonding began with the personal presentation and invitation for the child to play, assuming a peculiar design, according to the individual characteristics of each child.

Flavio was a boy who had difficulties with relationships and acceptance of treatment. In the first session, apparently ignoring the invitation to play, he took a few seconds and agreed to participate only by nodding his head, without verbalizing or looking at the researcher. Then he spent almost four minutes in silence, showing no interest in anything in the environment.

The first allusion that a bond was established occurred at the second session, when Flavio offered to the researcher, as a gift, a drawing made by him, clearly and spontaneously verbalizing:

This is yours! (Flavio)

Victoria was a cheerful girl, soft-spoken and very attentive to everything that happened around her. The signs of bonding gradually manifested beginning in the first session, when the girl, after handling and organizing the toys, opened the farm house, removed the animals, and began spontaneously to explain to the researcher:

The animals that live in the forest... They are seeing the farm. (Victoria)

From then on, the girl told a story to the researcher:

It is some houses near the farm. This is where the farmer lives. His grandpa and his grandmother came to visit him. Grandpa got sick.
He went to the hospital. He needed to receive intravenous saline solution. Then he got an injection. His grandpa was sad. (Victoria)

This was an indication that Victoria felt confident enough to create and expose an imaginary situation.

Bonding with SpongeBob began even before the researcher realized it. The boy watched her closely as she was playing with another child. Noticing his nearness, she introduced herself and asked him if he wanted to play, to which he responded with a broad smile and with positive nodding.

From the beginning of the first session, SpongeBob created imaginary situations that reported looking at the researcher while naming the characters, as if exploring the possibilities that she offered him, identifying an intersection with the next step, Exploring:

It's grandpa, and grandma! This one is the physician. This is my house and this is my family. (SpongeBob)

In the last session of SpongeBob, the bonding step was well established when the researcher entered the room, and the boy was waiting for her with open arms and introduced his new friend, a boy recently admitted to the unit.

In the case of Spider-Man, establishing the bond was difficult, because the boy smiled and was kind to all people who addressed him, showing, initially, no evidence of a specific bond with the researcher. The first obvious manifestation of bonding presented by the boy occurred only at the end of the first session when, handling the empty syringe, he smiled and finally looked directly at the researcher, saying:

It has wind. (Spider-Man)

\section{Exploring}

This step is characterized by the activities of examining, analyzing, and experimenting with the toys, the situation surrounding them, the environment, and those close or present during the session. While exploring, the child discovers the possibilities offered by playing.

Three manners of exploring were highlighted by the children in DTP sessions: observing, looking closely at the toys, the environment, the people and everything around them; handling the objects used to play; and verbalizing by asking questions about what he has explored.

In the Victory, SpongeBob, Spider-Man, and Batman cases, the children behaved very similarly at the beginning of the first session, looking closely at each toy as the researcher took them out of the bag.

Victoria watched and then handled the objects, giving them an initial set-up, as if she was setting the scenario to dramatize.

Spider-Man, in turn, even smiling, handled the toys and kept a close eye on them for most of the first session, not becoming distracted from them, even as hospital staff came in and out of the room to care for another child.

In his first session, Ben 10 initially watched the camcorder closely, for more than a minute, and soon after began looking at and handling the toys. The child's interest in the camcorder, 
as evidenced by the observation, suggests that he only visually explored the camera, showing no external signs of an imaginary situation, even though this could have happened.

Flavio, at the first session, a few minutes after he had agreed to play, showed some evidence that he was exploring, when he began to handle the toys visibly, involving motor skills and touch.

The questions asked by the children represented another manner to explore, evidenced in the DTP sessions. They were observed both in egocentric speech, when the child verbalizes asking himself, while observing and handling what he was exploring, as well as in social or communicative speech, where the child turns to another, using the question as request for assistance ${ }^{(23)}$.

An example of egocentric speech was perceived in the second session of Spider-Man, when he, concentrating, looking at a drawing he was making, asked himself aloud:

$$
\text { Now...? (Spider-Man) }
$$

Then, the boy presented social or communicative speech when, still on the same drawing, he looked at the researcher and asked her directly:

\section{Paint both of them, right? Now. (Spider-Man)}

Another example of social speech is when Flavio, about six minutes from the beginning of the third session, looking at the researcher and referring to the toys that included hospital supplies, asked her:

\section{What is this for? (Flavio)}

As the researcher told him that those things were for play, he continued to stare at the hospital supplies and, after a few seconds, seemingly surprised and pointing to the dolls, once again asked, pointing to the dolls:

Give them an injection...?! (Flavio)

The frequency of Flavio's experiences in which the hospital supplies had caused pain probably led him to internalize the concept that they would only be used for this purpose. However, after exploring, making sure that at that time the material would not be used to perform procedures on him, the boy was able to move to another step, dramatizing situations demonstrating the meanings that the material had for him.

\section{Dramatizing}

The DTP sessions analyzed in this study showed countless imaginary situations in which two major themes emerged, family and hospitalization, with significant manifestations of catharsis. An eloquent example was noted at SpongeBob's third session when, after representing the whole family with the dolls, he assumed the role of physician, saying:

Today I will do the physician's day. Today, I'm doing it as if I were the physician. (SpongeBob then represented the imaginary situation of giving injection to the dolls)
Spider-Man represented his family, especially in the second session, when he spent most of his time drawing, and when asked by the researcher who were the people he was drawing, replied:

It's my mom and dad! (Spider-Man)

Flavio, in his third session, represented imaginary situations related to hospitalization and procedures, when, for example, after exploring the material, handling the syringe and needle, he dramatized blood collection on the dolls, telling his mother:

I know how to draw blood mom! [...] I know. I stick the needle like that, oh! (Flavio)

From that moment on, Flavio dramatized hospitalization-related content throughout the most of the session. After some time giving injections into the dolls, the boy, perspiring a lot on his face, rubbed his forehead and, with an expression of joy on his face, commented:

I was even hot! (Flavio)

In the fourth session, Flavio played with the little farm, removing pieces and placing dolls inside the house, and when I asked him, who these people were, he replied:

The family. (Flavio)

Victoria dramatized some imaginary situations with the dolls, related to family, pain and discomfort caused by the appendicitis surgery she had undergone, represented in the statements:

Grandpa got sick. Then ... he got an injection. Grandpa was sad. Then he would get an injection, he was sad and the injection hurt! Then everyone said that he had a very serious illness and he was very sad. Then he asked, why did he have to be hospitalized? It's because he has to have surgery, because she has 'pendicitis.' The other day he was fasting, and then he was starving. (Victoria)

However, the girl showed optimism when, as she continued with the story she was building with the dolls, and, revealing her desire for a happy ending, said:

Then they lived happily ever after! (Victoria)

\section{Play cessation}

The TP technique recommends that the child should be warned a few minutes in advance that the end of the session is approaching. However, the cases in this study showed that in some sessions, the child accepted the end of the session, and in others, the drama with the hospitalization theme began from the moment the child was advised that the session was ending. It was also observed that, after being warned that the session was over, the child tried to prolong it, indicating that, for him, the play was not over.

This happened to Spider-Man who, in the first session, after being warned for the second time that time was running out, agreed to end the play by nodding, but continued to play, handling a syringe and a stopcock, as if they were forming a little plane, saying:

Look, the little plane! (Spider-Man) 
The child then played for a few more minutes, until the researcher once again asked him to store the playthings. He nodded, but put on a pair of procedural gloves, held them tight for a few seconds, until he finally pulled them off, and the session was over.

In the third session of the Flavio case, the boy talked and smiled spontaneously. During this session, he dramatized most of the time, and decided to close it himself by saying:

Idon't want to play anymore. (Flavio)

\section{DISCUSSION}

It should be noted that no publications focusing on the playing sessions were found, making it difficult to have a discussion regarding findings in the international literature. The term, to play, (in Portuguese, brincar) brings at its core the meaning of bond, since it originates from the word "brinco" (I play), which, in Latin, means to make ties, to bond ${ }^{(25)}$, showing that the development of a bond is an important part of the structure of this childhood activity.

Reinforcing the idea that play in childhood needs a bond, ludotherapy, which has the same theoretical bases as TP, has as its basic principle the establishment of "rapport"(26), pointing to the development of a harmonic bond, with respect and child acceptance.

The DTP sessions conducted in this research clearly highlighted the importance of forming a bond between the nurse and the child, so that they could be developed. During this step, the child observes the nurse, internalizing the concept that this professional is an adult he can trust in order to share his thoughts, feelings, fears, and emotions, because he/she respects her as well as her decisions.

The internalization of a concept or idea enables the internal reconstruction of an external operation. The child uses his senses in the external activities of observing and handling and, from his perceptions, reconstructs them internally, by means of higher mental processes, or higher psychological functions, developing a practical intelligence, voluntary attention, and memory ${ }^{(21)}$. Thus, we can understand that the child's concept of the nurse is the result of a sequence of interactions between them, characterizing a process of internalization.

These interactions do not necessarily require words or actions. The nurses' non-interference with children's decisions about playing, as a manifestation of respect for their choices, is an efficient form of interaction, which contributes to their internalization of the concept of the nurse as a reliable adult, although sometimes perform painful procedures.

Bonding with respect and understanding must be acknowledged to be an important thing. The bond requires attention and patience on the part of the nurse, because the absence of obvious manifestations of bonding by the child does not mean that this process is not happening, as could be observed in the case examples in the description of this step.

In the activity of exploring, the child has the opportunity to retrieve previous symbols in memory, establish connections with what he is currently observing, to reflect, and reorganize these feelings internally. Thereafter, he can seek new symbols that will mediate external activities, directly influencing his choices related to playing and the meanings that he attributes to interactions with the hospital environment, professionals, and procedures.
Speech can be a mediating activity for the child, which is part of his efforts to reach a goal or solve a problem, either by means of egocentric, social, or communicative speech in which the child speaks to others, such as in a manner to ask for help ${ }^{(21)}$. Knowing how to identify if the question is egocentric or social speech can help the nurse to maintain the non-directivity of the play, favoring the establishment of bond.

During the exploration, the child gathers elements so that, by means of higher psychological functions, among which Vygotsky emphasizes thought and language ${ }^{(23)}$, he redefines already known symbols in a dynamic process of internalization.

The child's observation of how the nurse behaves in relation to the playing is a continuous and subtle exploration, often silent and imperceptible, that can cause anxiety in the professional, whether she/he is prepared for it or not. Silence is the moment when the child internally elaborates, using his higher psychological functions, the information he has gathered by mean of exploration.

On exploring, the hospitalized child realize about his surroundings and the hospital, an unknown and sometimes hostile-looking world. The exploring step helps to minimize anxiety, stress and fears that the surroundings can cause, organizes themselves internally, maintains and strengthens the bond and manages the imaginary situation that will be dramatized.

An important function of the plaything is the role-play, conflict and catharsis, which means relief, purification of the individual, and constitute the basis of Ludotherapy ${ }^{(26)}$ and also of TP.

The dramatization in the DTP session enables the child to represent his or her desires or to mimic real circumstances that afflict, frighten, distress, or impress him most strikingly. In the articulation between imaginary situation and real circumstance, the child highlights the meaning that the real circumstance has for him/her, in order to understand and (re)signify it, as observed in the cases of this research.

For Vygotsky, the protagonized plaything, or make-believe play, enable the child to the possibility of understanding interactions that she cannot understand, as well as reframing the situation ${ }^{(23)}$.

Role-play is most closely related to the exploring and stopping play steps. In the activity of exploring, the child continues to internalize a concept about the nurse and prepares to dramatize it. Stopping playing is linked to the intensity with which the child has dramatized, performing catharsis of his fears and sufferings until that moment, as will be discussed below.

According to the DTP technique, the nurse must inform the child beforehand that she will have time to play and that she will notify when the end of the game is close. Thus, a DTP session is the space in which the child can play, exposing the concepts internalized by him, both during hospitalization, in his previous life and desires.

However, the nurse's statement that a session is ending does not mean the end of that play for the children. She, especially at school age, plays in consecutive sessions, as if there were no breaks between them, so, in a larger process, that one session is a continuity from the previous, in which the child herself decides the end.

Therefore, it is understood that the child has his own time to close a session, requiring the nurse to be aware, before ending the process of DTP. However, this process can span more than one session.

Each step of the session has its specific duration, determined by the functioning mechanisms of the child's higher mental processes. Understanding the different activities that characterize each of 
the steps provides greater confidence for the professional, who begins to respect the child's individual time during the playtime, and does not interpret silence exclusively as their disinterest.

The silence or apparent disinterest of the child during play is in fact an excellent opportunity for him to observe the nurse, and her conduct in a discreet and subtle interpersonal process. It is the moment when the child, internally, begins to organize to perform other activities and interact with the nurse, with the freedom to expose himself.

\section{Study Limitations}

The study was limited to cases related to the hospitalized child who was able to communicate verbally and to play, as well as being able to participate in the DTP session, because this modality requires more professional knowledge on the conduct and interpretation of symbolic manifestations of the child. Although these manifestations have been addressed, they have not been thoroughly explored because this was not specifically the object of this study and deserves to be better explored in other researches.

It is also necessary to study sessions of otherTP modalities, such as instructional play and physiologically enhancing play, as well as its use with children in other situations, such as in intensive care units or non-hospital care services, such as schools and day care centers.

\section{Contributions to the Nursing Area}

As the steps of the TP session had not yet been investigated, this research is the first step for further research seeking a more accurate understanding of children's play.
There is also the immediate contribution related to the conduct of the DTP session by nurses, regarding what this professional can expect in this session, how to behave, and what they must consider as relevant during its evolution. The knowledge of these aspects is relevant to promote greater professional safety when using TP with the child, hospitalized or not, contributing to the systematic implementation of this important interactional technology in pediatric nursing care.

\section{FINAL CONSIDERATIONS}

The research provided new findings, such as the fact that each DTP session has a distinct four-step process, "bonding; exploring; dramatizing; and play cessation". It also made it possible to understand how they are organized and articulated with each other.

The progression of this process helps the child to understand the meaning of the disease and hospitalization, reducing stress on the child and his family, strengthening everyone in the process of restoring the child's physical and emotional health, which when playing, exercises higher psychological functions.

Knowing the process of the DTP session enables nurses to plan and include this intervention in daily life, and to identify with confidence when their goals have been achieved.

Studying the TP sessions proved to be an appropriate method to know a little bit more about what happens to the child during playing, especially the interaction, articulation, and interdependence between the higher psychological functions, reinforcing once again the importance of inclusion of TP in nursing care practice with hospitalized children.

\section{REFERENCES}

1. Steele S. Child health and the family. New York: Massom; 1981. p.710-38

2. Pontes JE, Tabet E, Folkmann MA, Cunha ML, Almeida FA. [Therapeutic play: preparing the child for the vaccine]. Einstein [Internet]. 2015 [cited 2016 Jun 19];13(2):238-42. Available from: http://www.scielo.br/pdf/eins/v13n2/pt_1679-4508-eins-13-2-0238.pdf Portuguese.

3. Paladino CM, Carvalho R, Almeida FA. Therapeutic play in preparing for surgery: behavior of preschool children during the perioperative period. Rev Esc Enferm USP [Internet] 2014 [cited 2016 Jun 19];48(3):423-9. Available from: http://www.scielo.br/pdf/reeusp/v48n3/ pt_0080-6234-reeusp-48-03-423.pdf

4. Brenner M, Treacy MP, Drennan J, Fealy G. Nurses'perceptions of the practice of restricting a child for clinical procedure. Qualitative Health Research [Internet]. 2014 [cited 2016 Jun 19]; 24(8) 1080-1089. Available from: http://qhr.sagepub.com/content/24/8/1080.abstract

5. Matos APK, Canela PC, Silveira AO, Wernet M. Revelations expressed by preschool children with chronic diseases in outpatient treatment. Acta Paul Enferm [Internet]. 2014 [cited 2016 Jun 19];27(2):126-32. Available from: https://doi.org/10.1590/1982-0194201400023

6. American Academy of Pediatrics. Committee on Hospital Care and Child Life Council. Policy Statement.Child Life Services. Pediatrics [Internet]. 2014 [cited 2016 Jun 19];133(5):e1471-e1478. Available from: http://pediatrics.aappublications.org/content/133/5/e1471

7. Cruz DSM, Virgínia NA, Maia FSB, Martins DL, Oliveira AMS. [Therapeutic play: integrative review]. Rev Enferm UFPE[Internet]. 2013 [cited 2016 Jun 19];7(5):1443-8. Available from: http://www.revista.ufpe.br/revistaenfermagem/index.php/revista/article/viewFile/2833/pdf_2558 Portuguese.

8. Souza LPS, Silva CC, Brito JCA, Santos APO, Fonseca ADG, Lopes JR, Silva CSO, Souza AAM. [Therapeutic play and play in the nursing team vision]. J Health Sci Inst [Internet]. 2012 [cited 2016 Jun 19];30(4):354-8. Available from: http://www.unip.br/comunicacao/publicacoes/ics/ edicoes/2012/04_outdez/V30_n4_2012_p354a35.pdf Portuguese.

9. Souza A, Favero L. [Use of therapeutic play in nursing care of the hospitalized child with leukemia]. Cogitare Enferm [Internet]. 2012 [cited 2016 Jun 19];17(4):669-75. Available from: http://revistas.ufpr.br/cogitare/article/view/30364/19641 Portuguese.

10. Fonseca MRA, Campos CJG, Ribeiro CA, Toledo VP, Melo LL. Revealing the world of oncological treatment through dramatic therapeutic play. Texto Contexto Enferm [Internet]. 2015 [cited 2016 Jun 19];24(4):1112-20. Available from: http://www.scielo.br/pdf/tce/v24n4/pt_01040707-tce-24-04-01112.pdf 
11. Ribeiro CA, Borba RIH, Mello LL, Santos VLA. [Utilizing therapeutic play in care of the child.] In: Carvalho SD (org.). [The nurse and multidisciplinary health care of the child and adolescent.] São Paulo: Atheneu, 2012. p. 127-34. Portuguese.

12. Maia EBS, Ribeiro CA, Borba RHI. Understanding nurses' awareness as to the use of therapeutic play in child care. Rev EsC Enferm USP [Internet]. 2011 [cited 2016 Jun 19];45(4):839-46. Available from: http://www.scielo.br/pdf/reeusp/v45n4/v45n4a07.pdf

13. Oliveira CS, Maia EBS, Borba RIH, Ribeiro CA. [Therapeutic play in child care: nurses' perceptions of pediatric units of a university hospital]. Rev Soc Bras Enferm Pediatr [Internet]. 2015[cited 2016 Jun 19];15(1):21-30. Available from: http://www.sobep.org.br/revista/images/ stories/pdf-revista/vol15-n1/vol_15_n_2-artigo-de-pesquisa-3.pdf Portuguese.

14. Oliveira SR, Almeida NA. [The playful expressions as therapy in hospitalization: integrative review]. Gestão Saude[Internet]. 2016 [cited 2016 Jun 19];07(1):356-68. Available from: http://gestaoesaude.unb.br/index.php/gestaoesaude/article/view/532/pdf . Portuguese.

15. Conselho Federal de Enfermagem-COFEN - Resolution No. 0546. Rio de Janeiro, May 9, [Internet]. 2017[cited 2016 Jun 19]. Available from: http://www.cofen.gov.br/resoluo-cofen-0546/2017. Portuguese.

16. Baldan JM, Santos CP, Matos APK, Wernet M. [Adoption of play/toys in the care practice of hospitalized children: nurses' trajectory]. Cienc Cuid Saude [Internet]. 2014 [cited 2016 Jun 19];13(2):228-35. Available from: http://www.periodicos.uem.br/ojs/index.php/CiencCuidSaude/ article/view/15500/pdf_167 Portuguese.

17. Freitas BHBM, Voltani SSAA. Therapeutic play in the pediatric urgent and emergency department: an integrative literature review. Cogitare Enferm [Internet]. 2016 [cited 2016 Jun 19];21(1):01-08. Available from: http://revistas.ufpr.br/cogitare/article/viewFile/40728/27245

18. Malaquias TSM, Baena JA, Campos APS, Moreira SRK, Baldissera VDA, Higarashi IH. [The use of playthings during child hospitalization: nursing team knowledge and practices]. Cienc Cuid Saude [Internet]. 2014 [cited 2016 Jun 19];13(1):97-103. Available from: http://www. periodicos.uem.br/ojs/index.php/CiencCuidSaude/article/view/21802/pdf_118 Portuguese

19. Francischinelli AGB, Almeida FA, Fernandes DMS. Routine use of therapeutic play in the care of hospitalized children: nurses' perceptions. Acta Paul Enferm [Internet]. 2012 [cited 2016 Jun 19];25(1):18-23. Available from: https://www.scielo.br/pdf/ape/v25n1/en_v25n1a04.pdf

20. Berté C, Ogradowski KRP, Zagonel IPS, Tonin L, Favero L, Almeida Junior RL. [Therapeutic play in the context of pediatric emergency]. Rev Baiana Enferm [Internet]. 2017[cited 2016 Jun 19];31(3):e20378 Available from: https://pesquisa.bvsalud.org/portal/resource/pt/ biblio-897481 Portuguese.

21. Lemos I, Oliveira J, Gomes E, Silva K, Silva P, Fernandes G. [Therapeutic play during the venipuncture procedure: a strategy to reduce behavioral changes]. Rev Cuid [Internet]. 2016[cited 2016 Jun 19];7(1):1163-70. Available from: http://dx.doi.org/10.15649/cuidarte.v7i1.303 Portuguese.

22. Charon JM. Simbolic interacionism. An introduction, an interpretation, an integration. 10 ed. New Jersey: Prentice-Hall; 2010.

23. Vygotsky LS. The social formation of mind. 6ªed. São Paulo: Martins Fontes; 2003.

24. Yin RK. Case study. Planning and methods. 5aed. Porto Alegre: Bookman; 2015.

25. Freitas CJC, Martins MD. The significance of applying therapeutic play for a group of nursing students. Arq Med Hosp Fac Cienc Med Santa Casa São Paulo [Internet]. 2014 [cited 2016 Jun 19];59(1):16-9. Available from: http://www.fcmsantacasasp.edu.br/images/Arquivos_ medicos/2014/59_1/04-AO63.pdf

26. Brito RAC, Paiva VMB. Rogers' psychotherapy and Axline's play therapy: convergences and divergences. Rev NUFEN [Internet]. 2012 [cited 2016 Jun 19];4(1):102-114. Available from: http://pepsic.bvsalud.org/scielo.php?script=sci_arttext\&pid=S2175-25912012000100009 